Imagining and managing the nation: tracing citizenship policies in Serbia

Jelena Vasiljević

Institute for Philosophy and Social Theory, University of Belgrade, Serbia

www.instifdt.bg.ac.rs

jvasiljevic@instifdt.bg.ac.rs

jelena_vasiljevic@yahoo.com

To cite this article: Jelena Vasiljević (2012): Imagining and managing the nation: tracing citizenship policies in Serbia, Citizenship Studies, 16:3-4, 323-336

To link to this article: http://dx.doi.org/10.1080/13621025.2012.683162

ISSN 1362-1025 print/ISSN 1469-3593 online 


\title{
Imagining and managing the nation: tracing citizenship policies in Serbia
}

\begin{abstract}
This paper explores the most salient features of the reshaping of the state-territorynation triangle in Serbia over the last twenty years, through the lenses of citizenship regime. It looks at the ways in which the dominant political narrative in Serbia has imagined political community and accordingly managed its members. During the period of violent Yugoslav breakup and Milošević's rule the Serbian citizenship regime was surprisingly 'civic', while post2000 liberalization has introduced ethnic elements which are likely to be further strengthened. This apparent contradiction can be explained by the specific goals of Serbian political elites to maintain control over population and territory in changing political circumstances. I will argue that the legacy of different attempts at defining the relation between the Serbian state and the Serb people, coupled with the wider context of Yugoslav conflicts and post-conflict developments in the region, led to an unconsolidated citizenship regime in Serbia with varying and contested conceptions about how to achieve congruence of state, territory and nation.
\end{abstract}

Keywords: citizenship; citizenship regimes; Serbia

\section{Introduction: understanding political transformations through citizenship}

The discussion on citizenship in Serbia, as laid out in this paper, is a proposal to look at the citizenship regimes as reflections of (changing) trends in the ways the body of citizens and nation is being conceptualized and consequently managed within a given political community by its policy makers. It takes as its starting point Brubaker's (1998) idea that the politics of 
citizenship mirror specific ideas of nationhood - this paper sets out to show how the changing citizenship regimes in Serbia translate the varying narratives and perceptions of nationhood into the realities of political community. This is a perspective from which citizenship can be seen as a means of giving legal substance to the underlying idea of congruence between state and nation. Under exploration here will be the most salient features of reshaping the state-territory-nation triangle in Serbia over the last twenty years, observed through the lenses of citizenship regime and the ways in which the dominant political narrative in Serbia has imagined political community and accordingly managed its members. During the period of violent Yugoslav breakup and Milošević's rule the Serbian citizenship regime was surprisingly 'civic', while post2000 liberalization has introduced ethnic elements which are likely to be further strengthened. This apparent contradiction can be well explained by the specific goals of Serbian political elites to maintain control over population and territory in changing political circumstances. I will argue that the legacy of different attempts at defining the relation between the Serbian state and the Serb people, coupled with the wider context of Yugoslav conflicts and post-conflict developments in the region, led to an unconsolidated citizenship regime in Serbia with varying and contested (both internally and externally) conceptions about how to achieve congruence of state, territory and nation.

My approach will adopt a top-down perspective, looking at citizenship legislation and political solutions devised to manage the body of citizens, treating these policies as visible efforts to legally ground the imagined boundaries of the nation controlled by its polity. The research approach will rely on the model of questioning typical for the anthropology of policy which treats policy documents as cultural texts, as '...classificatory devices with various meanings, as narratives that serve to justify or condemn the present, or as rhetorical devices and 
discursive formations that function to empower some people and silence others' (Shore \& Wright 1997, p. 15).

Introducing narratives into social analysis calls for more clarification since the term itself oscillates between being taken for granted and mystifying purposes of its explanatory power. Narratives are basically defined as sequences of (human) experiences in time. These sequences are organized in a certain way - some are more prominent and take central place, while others are pushed to the back. Understanding the logic behind these arrangements reveals the ideological function of narratives, since it offers the codes for a preferred interpretation (Franzosi 1998). I am invoking here the use of the concept in the social sciences, where narratives were found to be interesting objects of analysis because of their cognitive and legitimizing potentials. By 'packing' contingent events in unifying stories, narratives provide an illusion of coherence to interpretations of complex social life; they could be seen as processes of cognitive patterning of different social facts into the fabric that lends meaning to reality. They are tools of interpretation of the reality. The employment of narrative structures - with actors, motives, purposes, obstacles - translates historical contingencies into national destinies (see more in Patterson \& Monroe 1998). It must be emphasised that, when talking about public narratives or national narratives, there is always a plurality of structures and interpretations; however, there is usually a dominant narrative whose elements prevail in public discourse, news coverage, politicians' rhetoric, and even in official and legal documents. Though it cannot hope to decode or even map the many different narratives that have made an impact on the political conditions in Serbia over the last twenty years, this paper will attempt to account for their presence and influence on the changing citizenship regimes. The main object of analysis remains the politics of citizenship and its role in defining Serbia's polity. 
Renewed interest in the theorisation of citizenship, evident from the growing literature on the subject matter from the 1990s onwards, was partly triggered by the break-up of the former socialist multinational federations. The dissolution of certain types of polities for the purpose of creating new and different ones 'raised anew deep questions about what binds citizens together into a shared political community' (Beiner 1995, p. 3). Citizenship, thus, primarily denotes formal state membership. But from it stems a more active dimension of citizenship: political rights and participation in political life that imbues the notion of citizenship with political power. Finally, citizens, in forming a political community and performing the rights that actively shape it, share a sense of communal belonging. Therefore, as Joppke (2007) suggests, it is useful to distinguish between citizenship as status, citizenship as rights and citizenship as identity. The identity aspect of citizenship is especially theoretically challenging, but at the same time highly problematic to grasp and understand, because of its pretensions of universality (i.e. universal citizenship rights that stem from citizenship status shared by all members of one state, as argued by T.H. Marshall) which are seen to be in collision with a multiplicity of contested and differently represented identities that, in turn, challenge the equality implied by the universal citizenship status. ${ }^{1}$ Thus, the 'identitarian struggles' and the politicised realm of groups' rights and groups' efforts to achieve legal recognition ${ }^{2}$, which to a large extent mark the political condition of our time (sometimes portrayed as a trend of 'global retraditionalization', see Milenković 2010, p. 127-148), are becoming intrinsic to any political project of (re)defining the body of citizens; status, rights and (politicised and many) identities are becoming increasingly harder to distinguish between, even for analytical purposes. This is especially true in the context of the post-Yugoslav countries where the issues of state consolidation are becoming dependent upon the efficient management of group identities (see Spaskovska 2010 and Sarajlić 2010). 
This paper will be mindful of these complexities and of the different registries of belonging citizenship implies, and will also adopt the claim that citizenship regimes should not be regarded as self-contained realms; even though the state still remains the main body of analysis when it comes to citizenship ${ }^{3}$, there are many indicators signalling that citizenship regimes influence each other, feed on each other and work within the context where citizens themselves are becoming active players using the 'opportunity structures' provided by the different citizenship regimes in which they operate. Therefore, Baubock's notion of the 'citizenship constellation' as 'a structure in which individuals are simultaneously linked to several political entities' $(2010$, p. 848) proves to be a very useful framework for thinking about the citizenship regimes of states that have overlapping spheres of political influences, as is the case of post-Yugoslav countries.

The post-Yugoslav citizenship constellation has been formed through wars which dissolved federal Yugoslav citizenship into its republican components out of which new state citizenships have been carved; the violent conflicts in which socialist Yugoslavia ended laid the foundations for the new states' (re)building processes and became inextricably intertwined with them. Each of the newly independent states faced the need to redefine its framework of political belonging (often within the context of war and politics of ethnic homogenization) and to delineate the new body of citizens (who is 'in' and who is 'out'). A new look at the transformations of the post-Yugoslav space from the angle of citizenship regimes will enable us to understand 'the legal foundations and social glue of the new communities' (Shafir 1998, p. 3). Citizenship both reflected and made possible the implementation of new national policies; almost as if it was an invisible driver of change. 


\section{Serbia within the new Yugoslav framework: the (mis)uses of citizenship}

The dissolution of the Socialist Federal Republic of Yugoslavia (SFRY) left Serbia and Montenegro united in a rump Yugoslavia - the Federal Republic of Yugoslavia (FRY), established in April 1992. In 2003 this was reconstituted as the State Union of Serbia and Montenegro; following the independence referendum Montenegro became an independent state in June 2006, leaving Serbia little choice but to declare its own independence formally on 5 June of the same year. Therefore, Serbia's path to independence was carved through the process of other republics seceding from Yugoslavia and leaving the union with Serbia; establishing an independent Serbia was not part of the Yugoslav secession process, but rather came as its final consequence, brought about by two partitions and, in recent years, challenged by Kosovo's secession.

The absence of pro-independence rhetoric in Serbia had much to do with Slobodan Milošević regime's legitimising strategies for staying in power in the 1990s and leading the FRY, which proclaimed legal continuity with the socialist Yugoslavia. Such claims were used to justify and portray violent conflicts in Slovenia and in Croatia in 1991 as federal army interventions aimed at preserving the federal state's sovereignty. The mobilising potential of the state's rhetoric of continuity remained strong throughout the conflicts, and was often invoked to blur Serbia's own expansionist policies. But the rhetoric of the Yugoslav legacy was also important for regulating affairs in Serbia proper. Even though often portrayed as extremely nationalistic (and often spoke of prioritising 'national interests' in its agenda) the Milošević regime relied heavily on the rhetoric of continuity with socialism and the Yugoslav ideals of 
toleration and multiculturalism, thus playing with and obtaining control over both pro-Yugoslav and nationalistic sentiments of Serbia's citizens (see Jansen 2005, p. 20-24).

One expression of the latter, present both in public narratives and in the rhetoric of the ruling elites of the late 1980s and 1990s was the perception that the positions of Serbia and Serb people were threatened in SFRY. That became the leitmotif of the 1980s popular unrests in Serbia, known as the 'anti-bureaucratic revolution'4 and was also articulated in public expressions of dissatisfaction with the constitutional changes and arrangements of SFRY ${ }^{5}$. The SFRY's constitutional changes that increasingly empowered the republican units over the federal centre and gave considerable autonomy to Serbia's two provinces of Vojvodina and Kosovo laid the backdrop of narratives portraying Serbia's national interests as sidelined and suppressed. The trend of decentralising the country - the confederalisation of Yugoslavia coupled with federalisation of Serbia $^{6}$ - triggered the growing sentiment that Serbia was increasingly underrepresented in Yugoslavia; that sentiment incorporated elements from the old nationhood narratives, stressing the dominant role of Serbia in the South Slav union and its wartime efforts (in both World Wars) that proved decisive for the establishment of the Yugoslav state in the first place; all of these narrative motives were interwoven into a presumption that Serbia had the 'right to be the first among the equals' (Bunce 1999, p. 116).

General dissatisfaction was expressed through demands for the transformation of the country, where national grievances merged with growing discontent over the socio-economic situation. A wave of riots and popular movements swept Serbia in the 1980s, reaching their highest intensity in Kosovo. A rising political star from the second half of the 1980s, the new leader of the League of Communists of Serbia, Slobodan Milošević, responded to these movements in a populist way that differed in style from old party leaders' approach, and by 
engaging in the so-called 'anti-bureaucratic' revolution against old cadres of the same party, won the hearts and minds of many.

Milošević's distinctive old party style rule that co-opted and instrumentalised growing nationalistic sentiments paved the way for centralising power in Serbia. However, while other Yugoslav republics elevated their ethnonational policies into legal acts through 'constitutional nationalism' (Hayden 1992) ${ }^{7}$, Serbia adopted a civic constitution in $1990^{8}$ with no traces of ethnic discrimination among its citizens. But at the same time, the Constitution abolished the autonomy of two Serbian provinces (Albanian-dominated Kosovo and to a high degree multiethnic Vojvodina) and enabled the centralisation of political power. Moreover - despite the civic Constitution - a political atmosphere was created in which many citizens were stripped of their civic and political rights and became susceptible to various manipulations.

This was illustrative of the gap that characterised Milošević's rule between the legal and rhetorical frameworks of his power, on the one hand, and his ethno-national policies on the other. In other words, the nationalistic fuel that kept him going was not the most visible marker of his rhetoric. ${ }^{9}$ However, the effects of Serbian ethno-politics were more than visible, not only during the wars in Croatia and Bosnia, but also in Serbia proper, most notably in Kosovo. The abolition of its status as an Autonomous Province was followed by the severe political and social discrimination of ethnic Albanians, who constituted the majority in the region. Even though Kosovo Albanians formally had citizenship of the FRY and Serbia, their rights were not secured - a situation which led to their self-exclusion and the establishment of parallel quasi-state institutions (on elements of the Kosovo quasi-state and quasi-citizenship policies in the 1990s see Krasniqi 2010). 
The fact that there was a large group of citizens who formally enjoyed all rights, but were in fact politically and socially excluded, illustrates the discrepancies between legal-political rhetoric and political reality. We could say that Kosovo Albanians were de facto excluded and that their exclusion took the form of the exclusion of 'the other' within the framework of nationalistic politics. But there was also another sizable group of people that was left de jure excluded during the 1990s, even though it belonged to the same ethnic core into whose society its entry was denied. These were Serb refugees from Bosnia and Croatia, whose difficult entry into the Serbian citizenry was deliberately achieved using citizenship legislature. Namely, FRY enacted its law on citizenship only in 1996, four years after the new Yugoslavia was established. One of the reasons for this delay could be, as is often argued, that the ruling elites were waiting to see the outcomes of the wars of Yugoslav succession, before determining a new pool of citizens. Those in possession of citizenship of the Republic of Serbia or of the Republic of Montenegro on 27 April 1992 (the day of the establishment of the FRY) became citizens of FRY ex lege (Art. 46). However, the new law imposed restrictive rules of access, especially for those who came to Serbia or Montenegro after that date, during the wars, and who were for the most part Serb refugees that fled in great numbers (more than half a million people) from Bosnia and Croatia. $^{10}$

By imposing restrictions on the acquisition of FRY citizenship a manoeuvring space for politically manipulating the refugees was wide open. Firstly, the official vocabulary insisted on the term 'expelled' (prognani) which was in line with the state's framing of the wars in neighbouring countries, in which it 'officially never took part'. Also, that expressed the expectation of the state that the 'expelled' would return from where they were expelled and not settle permanently in the FRY. On the other hand, the state was trying to resettle some of them in 
areas where Serbs formed a minority, for the purpose of changing the demographic balance. There are indications that citizenship, in these cases, was directly used as a tool of ethnic engineering, via blackmail strategies: e.g. citizenship access would be granted if the family settled in Kosovo (Rava 2010, p. 10).

However, a significant number of refugees remained stateless for a long time. ${ }^{11}$ The reason for this could also lie in the uncertainties regarding their political loyalties. Even though they were Serbs who fled from ethnic conflicts, coming to Serbia with Milošević in power portrayed as a safeguard of Serb interests - the ruling party could not count with ultimate certainty on their votes (if granted citizenship), since many refugees, especially those who fled from Croatia blamed the Belgrade regime for betraying them. ${ }^{12}$ This short illustration of two different groups being de facto or de jure excluded on different grounds, concisely reveals the ambiguous nature of the official narrative (the legal language of inclusive civil state, public advocation of multinational Yugoslavia and the 'duty' to protect Serbs' interests, both within and outside Serbia) and its discrepancy with actual practice. This, in turn, set the condition for alternative narratives to flourish, both nationalistic and anti-nationalistic, which targeted Milošević as either the traitor of Serbian national interests or as the one to be held most responsible for the wars and Serbia's isolation. This led to anti-Milošević narratives taking one of two forms: blaming him for causing the wars or blaming him for losing them.

\section{Serbia's new course: towards re-imagining the relation between nation, state and territory}


The main characteristics of Serbia's citizenship regime during the 1990s were its rigid structure (control of access to citizenship which affected mainly Serb refugees), de facto exclusion of its significant Kosovo population, and increasing loss of control over the territory of Kosovo. After the fall of Milošević's regime in October 2000, the politics on citizenship started changing as well, mainly by becoming less restrictive, but also by incorporating now visible and legally grounded elements of ethnification. Effective political control over Kosovo further weakened, but without the citizenship legislature making adequate responses to the new situation.

\section{Liberalization of citizenship}

Already in 2001, the federal parliament adopted changes to the existing law on citizenship, most notably a provision allowing dual citizenship, which, to a certain extent, made it easier for refugees to resolve their citizenship status. However, other issues, like the conflict between the federal and the republican laws on citizenship (Serbia didn't change its 1979 republican law on citizenship until 2004), as well as the question of citizenship of the Kosovo population, after the region was put under the direct interim international administration of the United Nations, remained unaddressed (YUCOM 2001).

Two years later, Serbia and Montenegro changed the framework of their common state. On February 2003, the FRY was transformed into the State Union of Serbia and Montenegro. Thus, Yugoslavia finally vanished from the geo-political vocabulary. The Constitutional Charter of the new state union between Serbia and Montenegro explicitly made republican citizenship superior to that of the Union; responsibility for citizenship issues was fully devolved to the 
republican ministries of interior. Setting the explicit primacy of the republican citizenship in the State Union meant that Serbia finally had to change its law on citizenship. The 2004 Law on the citizenship of the Republic of Serbia tried to improve and harmonise previous legal solutions with the international standards referring to acquisition and termination of the citizenship for the certain categories of people. It reflected visible efforts to incorporate the principles and norms of the European Convention on Nationality, even though Serbia had not ratified it (Miletić 2005, p. 41-44). The main goal of this law was to allow everyone to obtain the Republic of Serbia's citizenship who wished to, and who satisfied the basic criteria, which were easier than before (see the report on Serbia in Imeri 2006, p. 267-285).

For certain special categories of persons, even permanent residence on the territory of Serbia was no longer a requirement for entry into citizenship. Interesting too was the absence of any 'ethno-cultural criteria' (e.g. knowledge of Serbian language or the acceptance of Serbian culture), even though there were preferential conditions for admission into citizenship for persons belonging to Serb ethnicity. A very important feature of the actual law on citizenship is its toleration of dual and multiple citizenship (Art. 52) which works in the direction of resolving the status of refugees. The law also provides preferential treatment for several special categories of applicants. First, there is the possibility of acquiring citizenship by a mere written statement and without release from another citizenship for those belonging to Serbian nation (understood in ethnic terms) and for those belonging to any other national or ethnic group from the territory of Serbia (Art. 23).

Several important issues emerged from this legal re-conception of the body of citizens in a state that changed its political course (as well as its name and, after Montenegro's secession, sovereign status) and they will be approached, against the background of some other laws and 
the 2006 Constitution, in the following section. They include aspects of the ethnification of citizenship, the political significance of dual citizenship, and the (legal bypassing of) citizenship status of Kosovo residents.

\section{The constitutional conundrum}

In 2006, the loose state union with Montenegro fell apart. In the same year as it was left as an independent state, Serbia adopted a new Constitution, which now formally - but also at a symbolic level - broke the ties with its socialist past and the 'old state unions' by embracing the state insignia that evoked nineteenth century Serbian statehood. ${ }^{13}$ The adoption of the new Constitution had great symbolic importance, since it represented the first Constitution of an independent Serbia in more than a hundred years. It embraced the state symbols of the nineteenth century Serbia by adopting the royal coat of arms and the anthem that was in use until 1918. Obviously these resolutions testified to the attempts at creating a sense of continuity and rootedness in the allegedly stable traditions of statehood and nationhood. But, in fact, many other aspects related to the formulation and adoption of the Constitution revealed the ambiguities and contradictions of the 'old-new' state that was, in a way, in the process of its re-making: one of them clearly being the 'discrepancy between the featuring of clerical-monarchist icons - restored from the Kingdom of Serbia - on the one hand and the denomination of the modern Serbian state as a secular republic on the other' (Karamanić \& Šuber 2010, p. 16). The first article states that the country is founded on European values, the rule of law, human and minority rights, and principles of civic democracy. At the same time, Serbia is re-defined as a 'state of Serb people and all citizens living in it', therefore as an ethnic state, with the Serbian language and the 
Cyrillic alphabet as the only national language. Some noticed an irony in the fact the final constitutional arrangements of a state that advocated political community with others (Milošević's rhetoric on preserving Yugoslavia and then the insistence of Koštunica's government on the state union with Montenegro) eventually turned out to be those of an ethnic state (Malešević 2008).

Further analysis of the Constitution reveals more about the 'belonging conundrum' created by the inconsistent and unclear deployment of some of the main constitutional categories. For instance, the Preamble of the Constitution mentions 'the Serb people', 'all citizens and ethnic communities in Serbia' ${ }^{14}$ and part of its territory, Kosovo and Metohija. ${ }^{15}$ The way these different notions of belonging have been used in the same sentence, without clear explanation of their mutual relations - who is the bearer of the rights: members of the Serb people or citizens of Serbia? What is the difference? What is their relation to one part of the state mentioned in the same sentence of the Preamble? - suggest that the drafters of the Constitution did not pay much attention to defining frameworks and settings for the management of now constitutionally recognised different belongings (Brković 2008). Brković further notices, in her analysis of the Constitution of Serbia, the failure to reconcile incorporated elements of multicultural polices with the liberal state legal framework: the Constitution guarantees the protection of individual human rights, and values personal liberties and freedoms highly, but at the same time the Constitution presupposes - by various usages of notions like identity, culture and tradition as ontological givens - the belonging of all individuals to (ethno-national) groups and 'cultures'. Art. 64 illustrates the point that: 'Every child has a right...to maintain his or her identity'. Identity is clearly seen here as something that exists before the person is even born; it is implied that we acquire identity by the simple fact of being born in certain cultural surroundings. And 
what is even more worrying is that identity and culture are understood in the Constitution as ethnic identity and culture only, as Brković's analysis shows (ibid).

The Constitution takes into account the existence of different ethnic cultures in Serbia and even insists on ethno-cultural diversity and protection of ethnic minorities, but in a way that implies that Serbia is a community of (ethnic) communities. 'All citizens' from the Preamble seem to be completely absorbed by 'the Serb people' and 'ethnic communities in Serbia'. And not only is the civic element somehow lost in these 'belonging arrangements', but the equality of all ethnic communities is put in question as well. The initial differentiation between 'the Serb people' and other 'ethnic communities in Serbia' is replicated in many other legal settings. It is not just that the two 'categories' of citizens are often mentioned separately, it is the nature of the state's relation towards the members of these categories that is potentially problematic. On the

one hand we have 'ethnic communities' that live in Serbia, with their members being citizens of Serbia. On the other, Serbia is defined as 'a state of Serb people', meaning not only of those Serb members living and residing in Serbia; in other words, not only of those who are actually citizens of Serbia. An illustration of that can be seen in Art. 13 of the Constitution, on 'protection of citizens and Serbs abroad' (emphasis added): 'The Republic of Serbia shall protect the rights and interests of its citizens in abroad. The Republic of Serbia shall develop and promote relations of Serbs living abroad with the kin state'. Quite clearly, the second sentence demonstrates the resolution of the Republic of Serbia to engage in promoting relations with those who ethnically and not as citizens - 'own' it.

\section{Ethnification of Serbian citizenship}


Upon the enactment of the Constitution and the break-up of the State Union in 2006, Serbian citizenship law was slightly amended in 2007, mainly to reflect these changes. For instance, although the same conditions still apply for members of Serb people and members of any other nationality or ethnicity from the territory of Serbia who wish to obtain citizenship, the amended version distinguishes between ethnic Serbs who 'have the right to be admitted into citizenship' and persons of other ethnicities from Serbia 'who may be admitted into citizenship' (Art. 23, emphasis added). ${ }^{16}$ This differentiation was probably introduced to harmonise the law with the Constitution that defines Serbia as a state 'of Serb people and all citizens who live in Serbia'. This has, however, raised some questions about the 'ethnification' of citizenship, a question that obviously cannot be assessed with a sole focus on the law on citizenship.

Since the only criterion is ethnic belonging, that raises questions about how to validate claims of belonging to 'Serb people' in general and to any other ethnicity from the territory of Serbia. The usual procedure of validation involves proving a family relationship with a resident of Serbia who claimed belonging in past census records or who is affiliated with certain diaspora organisations abroad. This brings us to a need to consider the Law on Diaspora and Serbs in the Region, enacted in 2009. Mostly, it envisages the opportunities for cultural and economic cooperation, but the very need to initiate a special law on diaspora (and even the Ministry of Diaspora) and the new formulation of 'the Serbs in the region' could be taken as indicative of new politics of post-territorial 'reassembling' of the nation, understood primarily as the ethnic nation. Even though the Ministry of Diaspora tends to promote a more inclusive notion of diaspora, Art. 2 of the Law clearly distinguishes between two categories of that notion: citizens of the Republic of Serbia who live abroad, on the one hand, and members of the Serb people, both from the republic of Serbia and from the region, who emigrated, as well as their 
descendents, on the other. 'Serbs from the region' encompasses ethnic Serbs who live in the republics of Slovenia, Croatia, Bosnia-Herzegovina, Montenegro, Romania, Albania, and Hungary. Apart from protecting the rights and interests of members of the diaspora and Serbs from the region, the Law states as its goals the 'protection and fostering of the Serbian language and the Cyrillic alphabet, as well as Serbian cultural, ethnic, linguistic and religious identity' (Art. 4). It could be argued that such policies are in line with the new forms of ethnic nationalism, characteristic of the 'post-territorial citizenship' taking place in many postYugoslav states - 'where the presence on the territory is not anymore a relevant criterion of belonging to the community' (Ragazzi \& Balalovska 2010).

Another move towards 'de-territorialised' citizenship is the toleration of dual citizenship which entered into Serbian law in 2001. Although some authors argue that dual citizenship should be protected as a human right (Spiro 2010), in the post-Yugoslav space it raises many concerns. Its introduction in Serbia was intended to facilitate the status of refugees as well as the return of the diaspora whose help was expected in conducting political and economic reforms. Therefore, it signified first steps towards liberalisation of the citizenship regime, but at the same time it proved to have a problematic impact on the politics in the region. One example is the unsettled issue of double citizenship between Serbia and Montenegro. After Montenegro declared independence, a significant number of persons found themselves in an unfavorable position: Montenegrins who were citizens or residents of Serbia and Serbs who were citizens or residents of Montenegro. The Serbian Law provided preferential conditions for Montenegrins and dual citizenship, while Montenegrin Law on citizenship - due to specific voting arithmetic, internal political struggles between pro-Serb parties and the advocates of Montenegrin independence - prohibited dual citizenship (for more see Džankić 2010, p. 20-22 and in this 
volume). The situation is even more complicated due to strong social and familial connections between the citizens of the two countries. An agreement on the incompatibility between the two laws has not yet been reached.

Secondly, the question of dual citizenship per se raises the issue of state allegiance and state affiliation and its consequences bear specific importance for politically unstable states of the region. This is especially true with regard to consociational arrangements in BosniaHerzegovina, whose neighbours are 'national homelands' for a great number of Bosnian citizens. Although, Serbia has not been providing Serbian citizenship en masse to Bosnian Serbs, as was the case with Croatia and Bosnian Croats (Sarajlić 2010, p. 12), the politics of 'Serbs from the region' might be expected to encourage further steps in that direction. ${ }^{17}$

\section{The Kosovo impasse}

Even though the Constitution reflected noticeable symbolic attempts at projecting stability and Serbian statehood as a long durée fact, political reality revealed the territorial instability, its most effecting manifestation being the declaration of independence of Kosovo in February 2008.

On 10 June 1999 Kosovo was put under direct international administration in accordance with UN Resolution 1244. The administration and the legislative and executive power were placed in the hands of the United Nations Interim Administration Mission in Kosovo (UNMIK). Legally, Kosovo residents remained Yugoslav citizens, but UNMIK created a separate Central Civil Register of Kosovo which regulated residency status and issued travel documents to Kosovo residents. This was needed because many Kosovo residents were left without any identification papers after the NATO bombing. Kosovo Albanian officials stated that the civil 
registries were purposefully destroyed, while Serbian authorities claimed that all the registries were transferred to different Serbian municipalities. However, the situation regarding the regulation of citizenship status of Kosovars, after the implementation of the Resolution 1244, was such that Serbia continued to regard all Kosovars as its own citizens, although some possessed only the UNMIK documents, whereas some were still in possession of the FRY or Serbian documents, especially passports.

After unsuccessful negotiations between Serbia and Kosovo ${ }^{18}$, Kosovo's political representatives unilaterally declared independence on 17 February 2008. Based on the Ahtissari Plan, the adoption of the Constitution and the law on Kosovo citizenship followed soon after, with the aim of establishing Kosovo's initial citizenry (see Krasniqi 2010). Serbian citizenship policies towards Kosovo reflect all the complexity of the situation which has been developing since NATO's intervention. In its highest legal act as well as in its Law on citizenship, the state of Serbia does not reflect the factual changes that have occurred nor the fact that it has no effective control over the citizenship issues in Kosovo, since the presence of Serbian Ministry of Interior on the territory of Kosovo is constrained by Resolution 1244.

One of the effects of that situation was the non-inclusion of Kosovo residents in the Schengen visa liberalisation regime applied to Serbia in December 2009. According to the EU's stance, since it could not exercise control over the territory, the Serbian Ministry of Interior was not in a position to issue biometric passports to Kosovo residents, required for the visa-free travel into the Schengen space. This has created a situation where the whole population of Kosovo is affected by discriminatory citizenship practices such as exclusion of people from one region (or, at least, tacit complicity in the EU imposed exclusion) from the benefits enjoyed by all other citizens. In addition, the very same region is regarded as an integral part of Serbia's territory - 
which is repeatedly mentioned even in the Constitution's Preamble. Kosovo's authorities meanwhile issue their own documents and passports which Serbia does not recognise. These issues, together with the presence and activism of the Serbian state in the northern parts of Kosovo work in the direction of effectively creating competing citizenship regimes in Kosovo, that in itself remains a contested territory.

What is interesting here is the interplay between different socio-political elements which call into question the proclaimed citizenship policies and the higher political goals they serve. Serbia's inability to provide visa-free travel to a whole group of its citizens residing on the territory Serbia emphatically considers its own testifies clearly to its incapacity to exercise control over that territory; even more so, it testifies to the elasticity of citizenship's political value. Clearly, tangible benefits gained from the pro-European course of the Serbian government - such as the final abolition of visas - are assessed, even though not openly, as greater achievements for citizens' status than insisting on territorial sovereignty on all issues would ever be. On the other hand, even though they would never recognize Serbia as their state, Kosovo Albanians have been trying (and often succeeding) to obtain Serbian biometric passports and thus travel freely into the Schengen space, by claiming fictional residence on the territory of Serbia and using their Serbian citizenship. ${ }^{19}$ Different structures of opportunity, exercised both on the part of the Serbian state and by Kosovo Albanians interfere with official citizenship policies, highlighting the practical value of citizenship that goes beyond its political and identitarian aspects.

\section{Conclusion}


On a more general level, this brief overview of the main citizenship related issues in Serbia reveals how citizenship can offer a crucial insight into the wider political processes taking place in one polity; similarly, citizenship policies themselves become more exposed when analysed against the background of wider symbolic-cognitive framings of socio-political trajectories.

This paper has provided limited, but instructive insights into the major topoi that marked the citizenship regimes in Serbia over the last twenty years, by looking at and contextually connecting some of the legal documents, actual practices and political climate. Its guiding aim was to be mindful of the narrative structures that can always be found in the background of policies. But narratives are often contested and fluid since they serve changing political goals, and in the case of Serbia, variations in narrative portrayals of the state-nation-territory unity have been reflected by changing citizenship regimes.

After the dissolution of SFRY, Serbia faced the challenge of managing a differently conceived citizenry, despite the rhetoric of continuity and despite the fact the Republican law on citizenship remained unchanged. The ambiguous and ideologically incoherent politics of the 1990s was reflected in discrepancies between the legal framework and political practice. Statepreserving and anti-secessionist rhetoric did not prevent major exclusions and discriminatory politics, whereby citizenship was mainly a tool of preserving one political structure by controlling access to electoral rights. This resulted in a citizenship regime that proved 'smaller' than the body of citizens the polity wanted to control (which included Kosovo Albanians and Serbs from Bosnia and Croatia).

New political directions, taken after 2000, showed inabilities to coherently connect state, nation, and territory; the major tendencies were towards liberalization, and certain aspects of ethnification and post-territorial citizenship. Extraterritorial citizenship policies, aimed at both 
diaspora Serbs and those from the region remain unclear and produce dissatisfaction in the region; Serbia's attempts to influence Serbs living in neighbouring countries is an especially sensitive issue given its past expansionist politics. New constitutional and legal settings, that have both liberalized and ethnified the rules of access, are yet to produce palpable political consequences. Finally, even though conceptually stretching its spheres of influences (over those who do not reside in the country), the citizenship regime is diminishing its territorial outreach, by effectively losing almost all control over the territory of Kosovo and its residents.

In addition, the Serbian citizenship regime is increasingly overlapping with other existing regimes, not only that of Kosovo, but also, due to the political question of 'Serbs in the region' and dual citizenship, of Montenegro and Bosnia and Herzegovina. Politics in the region, coupled with the EU integration perspectives - which is opening new political and practical venues - will continue to pose new challenges on the ever changing and never consolidated citizenship regime of Serbia.

Acknowledgements

The financial support of the European Research Council (CITSEE, ERC 230239) in the preparation of this special issue is gratefully acknowledged. 


\section{References:}

Barry, B., 2001. Culture and equality. Cambridge: Polity Press.

Baubock, R., 2010. Studying citizenship constellations. Journal of ethnic and migration studies, $36(5), 847-859$.

Beiner, R., ed., 1995. Theorizing citizenship. Albany: State University of New York Press.

Brković, Č., 2008. Upravljanje osećanjima pripadanja: Antropološka analiza "kulture" i “identiteta” u Ustavu Republike Srbije. Etnoantropološki problemi, 3(2), 59-76.

Brubaker, R., 1998. Immigration, citizenship and the nation-state in France and Germany. In G. Shafir, ed. The citizenship debates. Minneapolis: University of Minnesota Press, 131-164.

Bunce, V., 1999. Subversive institutions. Cambridge: Cambridge University Press.

Cowan, J. K. et al. (eds.), 2001. Culture and rights. Cambridge: Cambridge University Press.

Džankić, J., 2010. Lineages of citizenship in Montenegro. CITSEE Working Paper. School of Law, University of Edinburgh.

Dragovic-Soso, J., 2008. Why did Yugoslavia disintegrate? An overview of contending explanations. In: L. J. Cohen \& J. Dragović-Soso (eds.), State collapse in South-Eastern Europe. West Lafayette, IN: Purdue University Press.

Franzosi, R., 1998. Narrative analysis - or why (and how) sociologists should be interested in narrative. Annual Review of Sociology, 24, 517-554.

Gagnon, V. P., 1995. Ethnic nationalism and international conflict: the case of Serbia. International Security, 19(3), 130-166. 
Grujić, J., 2006. The refugee electorate: past, present and future. Migration online [online]. Available from: http://www.migrationonline.cz/e-library/?x=1963588 [Accessed 15 January 2011].

Hayden, R. M., 1992. Constitutional nationalism in the Formerly Yugoslav Republics. Slavic Review, 51(4), 654-673.

Imeri, S., 2006. Rule of law in the countries of the Former SFR Yugoslavia and Albania between theory and praxis. Gostivar: Association for Democratic Initiatives.

Jansen, S., 2005. Antinacionalizam. Belgrade: XX vek.

Joppke, C., 2007. Transformation of citizenship: status, rights, identity. Citizenship Studies, 11(1), 37-48.

Karamanić, S. and Šuber, D., 2011. The visual between norm and excess. In: E. Pistrick, N. Scaldaferri and G. Schworer (eds.), Audiovisual media and identity in Southeastern Europe. Newcastle upon Tyne: Cambridge Scholars Publishing.

Krasniqi, G., 2010. Citizenship as a tool of state-building in Kosovo: status, rights, and identity in the new state. CITSEE Working Paper, School of Law, University of Edinburgh.

Kymlicka, W., 1995. Multiculturalism: A liberal theory of minority rights. Oxford: Clarendon Press.

Lampe, J. R., 1996. Yugoslavia as history: Twice there was a country. Cambridge: Cambridge University Press.

Malešević, M., 2008. Nasilje identiteta. In: Kulturne paralele: svakodnevna kultura u postsocijalističkom periodu. Beograd: Etnografski Institut SANU.

Marion Young, I., 1989. Polity and group difference: A critique of the Ideal of Universal Citizenship. Ethics, 99 (2), 250-274. 
Milenković, M., 2010. Ka politici srpske antropologije u 21. veku. Beograd: Odeljenje za etnologiju i antropologiju Filozofskog fakulteta u Beogradu i Srpski genealoški centar.

Miletić, S., 2005. Zakon o državljanstvu Republike Srbije sa komentarom i prilozima. Beograd: Službeni list Srbije i Crne Gore.

Nash, K., 2000. Contemporary political sociology. Globalization, politics, and power. Oxford: Blackwell.

Patterson, M. and Monroe, K. R., 1998. Narrative in political science. Annual Review of Political Science, 1, 315-331.

Ragazzi, F. and Balalovska, K. (forthcoming), Diaspora politics and post-territorial citizenship in Croatia, Serbia and Macedonia. CITSEE Working Paper, School of Law, University of Edinburgh.

Rava, N., 2010. Serbia: elusive citizenship in an elusive nation-state. CITSEE Working Paper, School of Law, University of Edinburgh.

Sarajlić, E., 2010. A citizenship beyond the nation-state: dilemmas of the 'Europeanisation' of Bosnia and Herzegovina. CITSEE Working Paper, School of Law, University of Edinburgh.

Shafir, G., ed., 1998. The citizenship debates. Minneapolis: University of Minnesota Press.

Shore, C. and Wright, S., eds., 1997. Anthropology of policy. London/New York: Routledge. Soysal, Y., 1994. Limits of citizenship. Migrants and postnational membership in Europe. Chicago: University of Chicago Press.

Spaskovska, L., 2010. In search of a demos: transformations of citizenship and belonging in the Republic of Macedonia. CITSEE Working Paper, School of Law, University of Edinburgh. 
Spiro, P. J., 2008. Beyond citizenship. American identity after globalization. Oxford: Oxford University Press.

Spiro, P. J., 2010. Dual citizenship as human right. International Journal of Constitutional Law, 8(1), 111-130.

Taylor, C., 1992. Multiculturalism and the politics of recognition. In: A. Gutmann (ed.), Multiculturalism: Examining the Politics of Recognition. Princeton: Princeton, NJ.

Vladisavljevic, N., 2008. Serbia's antibureaucratic revolution. Hampshire \& New York: Palgrave Macmillan.

YUCOM, 2001. Serbian-Montenegrin relations and the question of citizenship of FRY citizens, Executive summary. Belgrade.

\footnotetext{
${ }^{1}$ For an overview of critiques directed at the concept of citizenship as universal political category, see Nash 2000, p.156-216.

${ }^{2}$ Well-known theoretical models of 'group differentiated citizenship' (Marion Young 1989), 'politics of recognition' (Taylor 1992) and 'multicultural citizenship' (Kymlicka 1995) all call for reconceptualization of classical model of national citizenship so that it could account for different identities. However, many have criticized these approaches for their effects on ethnification of politics and for what is perceived as devaluation of universal humanism (see Barry 2001; Cowan et al. 2001).

${ }^{3}$ Despite the growing body of work pointing at either 'devaluation of citizenship' or different forms of transnational citizenship where the role of the states is becoming increasingly diminished (Spiro 2008; Soysal 1994 etc.), we cannot disregard the fact that citizenship status remains primarily regulated within the state framework.

${ }^{4}$ On the interaction between regime elites and the masses in these events see Vladisavljević 2008.

${ }^{5}$ Many of the growing grievances found their expression in the notorious Memorandum, the draft document of the Serbian Academy of Sciences and Arts that was leaked to the press in 1986. Although it became common in the
} 
scholarly analysis of Serbian nationalism to portray the Memorandum as a document envisioning Greater Serbia's plans and providing 'ammunition for Milošević's nationalist campaign' (Lampe 1996, p. 6), much of these representations exaggerate the content of the text itself (but probably not the context of its production and consequent instrumentalisation). See more in Dragović-Soso 2008, p. 18-20.

${ }^{6}$ The 1974 SFRY Constitution almost gave sovereignty to Yugoslav republics with similar competences, even to the Serbian provinces of Vojvodina and Kosovo. The functioning of the confederal political system on the basis of 'one republic one vote' created a basis for the narratives of neglected Serb interests, given the fact that the Serbs constituted the largest ethnic group in the SFRY (some 36 percent of the total population), but more than a third of them (in 1981, 3 million of the over 8.1 million in total) resided outside the Socialist Republic of Serbia.

${ }^{7}$ Commenting on newly installed constitutional arrangements that favoured dominant ethnic groups, often by denaturalising large numbers of residents (belonging to minor ethnic groups), while at the same time adopting large numbers of non-residents (of 'appropriate' ethnic origin), Hayden has nicely noted: 'A better example of the power of the imagined community to destroy actually existing communities would be hard to find' (Hayden 1992, p. 666).

8 'The Republic of Serbia is a democratic state of all citizens living within it, founded upon the freedoms and rights of man and citizen, the rule of law, and social justice' (Art.1).

${ }^{9}$ One way to understand the linkage between the centralisation of power and avoidance of open nationalistic rhetoric is to look at it through prism of Gagnon's deconstruction of the idea that the wars in Yugoslavia were ethnic wars. He saw in Milošević's rule a continuation of practices previously employed by the conservative elite in the SFRY: whenever threatened with new political forces with potential to take over its own privileges, the elite would delegitimize them on the accounts of being nationalistic and secessionist (Gagnon 1995, p. 130-166). Thus nationalism and secession were conveniently used as a pretext for greater centralisation and preservation of power, and in Milošević's Serbia even for military engagement. Higher ideological ends, seemingly above and beyond nationalistic aims would justify the concentration of all power. In the rhetoric of Serbian leadership and statecontrolled media nationalism became the feature of others/enemies ('separatist' Slovenians, 'irredentist' Albanians, 
'fascist' Croats or 'fundamentalist' Muslims) and openly endorsing its 'qualities' on the domestic terrain, in circumstances created by Milošević's way of ruling, would have had delegitimising effects.

${ }^{10}$ They could register as citizens, but they were required to make an application at the Federal Ministry of the Interior for 'entry' into the register of citizens provided they had lost another citizenship (Art. 47). The application had to be made within one year of the date when the law came into force. However, they had difficulties in obtaining permanent residence (required for the entry into citizenship) in accordance with the laws at that time (Rava 2010, p. 9).

${ }^{11}$ Some data indicate that only around third of applications for citizenship status was accepted (Rava 2010, p. 9).

${ }^{12}$ For more on refugee political preferences in Serbia see Grujić 2006.

${ }^{13}$ On reasons and interpretations for evoking nineteenth century Serbia's state symbols see Malešević 2008.

${ }^{14}$ Again, in art.1: 'Serbia is a state of Serb people and all citizens living in Serbia', Official Gazette of the Republic of Serbia, 98/2006.

${ }^{15}$ It is mentioned three times in the Preamble: as having 'substantial autonomy within the sovereign state of Serbia' and: 'from such status of the Province of Kosovo and Metohija follow constitutional obligations of all state bodies to uphold and protect the state interests of Serbia in Kosovo and Metohija in all internal and foreign political relations'.

${ }^{16}$ Easy access to citizenship is also offered to emigrants from the territory of Serbia and their descendents (art. 18) and to all former citizens of Serbia who lost their citizenship, mainly due to former intolerance of dual citizenship (art. 34). And, finally, a foreigner (and his or her wife or husband) could be granted citizenship, without meeting any conditions, if considered to be in the interest of the state (art. 19).

${ }^{17}$ It remains indicative that the President of the Republic of Srpska, Milorad Dodik, was admitted to the citizenship of Serbia in 2007.

${ }^{18}$ The status process negotiations began in October 2005. Since no compromise was reached after two years of negotiations, Martti Ahtisaari, in the role of the Special Envoy of the Secretary-General of the United Nations for 
the future status of Kosovo presented in March 2007 the Proposal for the Kosovo status Settlement, the so-called Ahtisaari Plan, to the Security Council. Due to Russia's objections, the negotiations continued, but without any result.

${ }^{19}$ See http://www.blic.rs/Vesti/Drustvo/175714/Zitelji-Kosova-Za-srpski-pasos-placaju-5000-evra and http://www.blic.rs/Vesti/Hronika/215963/Dacic-U-toku-oduzimanje-fiktivnih-pasosa [Accessed May 2010]. 